\title{
UNDESCRIBED WILLOWS OF 'THE SECTION CORDATAE
}

\author{
CARLETON R. BALL \\ (WITH ONE FIGURE)
}

While this paper is a continuation of the series which has appeared under the title Notes on North American willows, ${ }^{\text {I }}$ this general title is dropped now in favor of a specific one for each contribution. This seems desirable because it will permit a clear indication of the contents of each paper in the title thereof. These papers have resulted chiefly from studies made in preparing the treatment of the genus Salix for different floras and manuals of botany. ${ }^{2}$

The location of the herbarium material cited is indicated by capital letters in parentheses, as follows: B, herbarium C. R. Ball; C, herbarium Canadian Geological Survey, Ottawa; F, Field Museum, Chicago; FBb, Bebb Herbarium of Field Museum; Fs, Forest Service, United States Department of Agriculture; G, Gray Herbarium, Harvard University; I, Iowa Agricultural College; N, United States National Herbarium; R, Rocky Mountain Herbarium, University of Wyoming; RMP, herbarium of Rocky Mountains Park, Banff, Alberta, Canada.

SALIX LUTEA famelica, n.var.-Shrub or small tree, 3-6 m. tall; branchlets grayish, those of the season yellow, rather short and divaricate, glabrous: leaves small, stipulate; stipules mostly minute, I-3 mm. long, ovate to lanceolate, acute; petioles slender, 4-8 $\mathrm{mm}$. long, yellowish, glabrous; blades linear-oblanceolate, narrowed and acutish or somewhat rounded at base, acute to

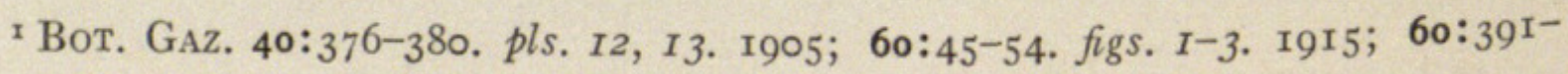
399. I9I5.

${ }^{2}$ Ball, Carleton R., Salix in Coulter and Nelson, Man. Bot. Rocky Mountain Region. pp. 128-139. 1909.

- Salix in PIPER and BEATtIE, Flora of the Northwest Coast. pp. I1 $3^{-118 .}$ November 1915 .

- Salix in P. C. Standley, Flora of Glacier National Park, Contrib. U.S. Nat. Herb. 22:319-324. March I921.

- Salix in Chas. C. DeAM, Trees of Indiana, revised ed. pp. 34-45. pls. IO-I4. I92I. 
acuminate at apex, 5-6 cm. long, 8-10 $\mathrm{mm}$. wide, on vigorous shoots 7-10 cm. long, I $2-20 \mathrm{~mm}$. wide, yellowish green, glaucous beneath, glabrous and strongly reticulate on both sides, margins cartilaginous and shallowly serrulate, or subentire: pistillate aments small, $2-3 \mathrm{~cm}$. long, on short peduncles $\mathrm{I}-3 \mathrm{~mm}$. long, subtended by 2 or 3 small leaves: capsule glabrous, lanceolate, $4 \cdot 5^{-5} \mathrm{~mm}$. long; pedicel $\mathrm{I}-\mathrm{I} .8 \mathrm{~mm}$. long.

This variety differs from $S$. lutea chiefly in the very small and more strongly nerved leaves. The aments and the pedicels both are shorter than the average for the species. It holds much the same relation to $S$. lutea as var. angustata does to $S$. cordata. The demarcation seems sharper in the present case, but this may be due to the limited number of specimens in hand. The name means starved or hungry, and is suggested by the attenuate leaves with their prominent "ribs."

The earliest collection seen by the writer was made in $188_{3}$ by L.F. Ward, on an island in the Yellowstone River, I 2 miles above Glendive, Montana. The type was collected by the writer about $\mathrm{I} 20$ miles farther up the Yellowstone River. S. lutea is very abundant on the floodplain of the river at Forsyth, Montana. Several clumps of shrubs were examined, probably fifteen or twenty in all, but only one was referable to the present variety. It consisted of only two or three stems, $8-10 \mathrm{~cm}$. in diameter at the base, and ${ }_{5}-6 \mathrm{~m}$. tall, located scarcely more than ro rods from the north edge of the little town. It was recognized at sight as differing in some way from the other clumps, and this difference was found to be in the size of the leaves.

WARD's specimen almost exactly matches the type, although the leaves are younger and smaller, the date of collection being six weeks earlier. The specimen from the Bellefourche River in South Dakota resembles $S$. cordata angustata a little more, just as the specimens of $S$. lutea from the Black Hills vary somewhat toward $S$. cordata. Further search probably will locate the variety in other parts of the Yellowstone Valley and in other districts. The first four specimens cited are all from one general district. The Bitter Root specimen is fragmentary and not well preserved, and hence somewhat doubtfully referred here.

South Dakota.-Bellefourche, along Bellefourche River, C. R. Ball I347, September I9, I908 (B).

NoRth Dakota.-Marmarth, wet bottoms, Little Missouri River, L. C. Moyer 469, June 6, I9r4 (B).

Montana.-Osprey Island in Yellowstone River, I 2 miles above Glendive, L. F. Ward, July $\mathrm{I}_{7}, \mathrm{I}_{88}$ (FBb 2380 ); Forsyth, north edge of town, C. R. Ball I304, September I, I908 (B, type; N); Bitter Root Valley and Mountains, Warm Springs Creek, alt. $7500 \mathrm{ft}$., Pammel and Fawcett, August 2I-September 2, 1904 (B, I). 
SAlix Lutea ligulifolia, n. var.- $S$. cordata, in part, as interpreted by ВЕВB, Willows of California, 85,1879 , and ВЕВB in Coulter, Man. Bot. Rocky Mt. Reg. p. 335. I885.-S. cordata Watsoni, in part, as interpreted by BALL, in Coulter and NELSON, New Man. Rocky Mt. Bot. p. I32. I909.

When first studied this willow was regarded as a species intermediate between $S$. cordata and $S$. lutea, and a detailed description was written. Later it was considered more properly placed as a variety of $S$. lutea, but the complete description has been allowed to stand. It is hoped that fuller field study may be given to this interesting form.

Shrub with clustered stems I. $5-3.5 \mathrm{~m}$. tall; bark dark gray; branchlets elongated, dark brown or somewhat yellowish, glabrous and usually shining, or the youngest pubescent; buds ovatelanceolate, $5^{-10} \mathrm{~mm}$. long, acute or obtusish, glabrous or pubescent, bright chestnut to dark brown, drying black: leaves mid-sized, petiolate, stipulate; stipules semicordate and acute to semilunate and obtuse, $4^{-10}$ or more $\mathrm{mm}$. long, entire or serrulate, glabrous, glaucous beneath; petioles 6-10 $\mathrm{mm}$. long, dark brown, glabrous to puberulent to pubescent, as the twigs; blades ligulate-lanceolate or oblong-lanceolate (narrowly oblanceolate when young), acute or very short-acuminate, rounded or subcordate and usually oblique at base, $5^{-10} \mathrm{~cm}$. long, $\mathrm{I}-2 \mathrm{~cm}$. wide, common sizes 5 by I. $2-\mathrm{I} .5$, 7 by $1 \cdot 3^{-1} .8,8$ by 2,9 by $1.5^{-2}$, and ro by $2, \mathrm{~cm}$., entire or (especially on vigorous sterile shoots) shallowly and remotely serrulate or glandular-serrulate, reticulate on both sides, especially beneath, dark green above, pale and at maturity usually white glaucous beneath, glabrous throughout or the white midrib puberulent above near base: aments appearing with the leaves or somewhat precocious, sessile, or the pistillate on peduncles $3^{-5} \mathrm{~mm}$. long; pistillate aments $2-3.5 \mathrm{~cm}$. long, subsessile, or on peduncles $3-5 \mathrm{~mm}$. long, subtended by $2-4$ very small leaves; scales elliptic-oblong, obtusish, drying black, glabrate outside at apex, basal portion and inside densely white-tomentose: capsule small, lanceolate or ovate-lanceolate, 4-5.5 mm. long, glabrous; pedicel I-I.5 mm. long, glabrous; style $0.3-0.5 \mathrm{~mm}$. long; stigmas short, entire, notched or bifid: staminate aments sessile, naked at base, or with one or two small bracts, slender, $2-3 \mathrm{~cm}$. long, $4-8 \mathrm{~mm}$. wide; 
stamens 2, filaments slender, glabrous, free; scales as in pistillate ament.

S. lutea ligulifolia is a mountain-loving form. It is found in the Rocky Mountain system from the Black Hills of South Dakota, and the Laramie Hills and Medicine Bow Mountains of southeastern Wyoming, south to southern New Mexico and central Arizona. An isolated distribution occurs in extreme western Nevada and the adjacent Yosemite Valley of California. It appears to be confined to stream banks in mountain canyons at elevations from $5000 \mathrm{ft}$. ( $1500 \mathrm{~m}$.) to probably $9000 \mathrm{ft}$. (2700 m.), although its upper limits are unknown as yet. It flowers from the last week in April until well into May, and fruits in due season thereafter.

It is distinguished from typical $S$. lutea by usually dark brown branchlets, longer and narrower, straplike, usually dark green leaves, with the margins often nearly parallel and usually entire or only shallowly serrulate. The capsules also are shorter and on fairly short pedicels. Specimens collected when the leaves are just unfolding resemble $S$. irrorata, but may be distinguished by somewhat lighter colored twigs, without the glaucous bloom, and by the broader, less oblanceolate leaves and longer pedicels. The following specimens are referred here.

California.-Yosemite Valley, H. N. Bolander 633 I, June 3 , I866 (FBb $6335, \mathrm{~N})$.

Nevada.-Washoe County, Hunter's Canyon, vicinity of Reno, I350I $500 \mathrm{~m}$., A. E. Hitchcock 455, July I8, I9I3 (N); no locality (probably Washoe County) Lieut. Wheeler, $\mathrm{I} 872$ (N, twig densely pubescent); Soda Springs

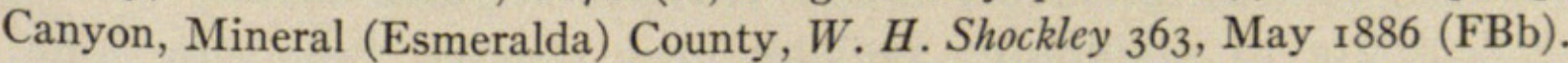

Arizona.-Grand Canyon, Indian Gardens, alt. $3800 \mathrm{ft} .$, E. A. Goldman 2237, August 25, I9I3 (N, twig densely pubescent); Navajo County, Black Mesa Forest Reserve: Black Canyon, Houck's Ranch, F. V. Coville ro 4 , June 5, I900; along creek at Showlow, Coville 1091, June 8, 1900; 2022, July 4, ${ }_{1904}(\mathrm{~N}$, both specimens with pubescent-pilose young twigs and broader and more serrulate leaves); Apache County, Springerville, alt. $7000 \mathrm{ft}$., E. A. Goldman 2446, June 8, I9r5 (N); White Mountain Indian Reservation; watershed of White River above Ft. Apache, Coville 1977 (N 500639, type), I981, June 30, r904 (N); White Mountains, south of Thomas Peak, Coville 20r4, July 2, I904 (N); along White River near Ft. Apache, Coville 2016 and 2020 (seasonal twigs pubescent, leaves broader and more serrulate), July 3, I904 (N); White Mountains, head of Black River, L. N. Goodding I 21 2, July I8, I9r 2 (N); White Mountain Apache Reservation, Myrtle Zuck, June 25, $1907(\mathrm{~N})$.

UTAH.-Kane County, Three Lakes, north of Kanab, I. Tidestrom 2417, July 9 , r 909 (B).

New Mexico.-No locality (probably Silver City, Grant County), E. L. Greene (FBb 3908, in part); Grant County, Ft. Bayard, Stephen's 
Ranch, J. C. Blumer I7I, November I5, I905 (B); Lincoln County, White Mountains, alt. 7000 ft., E. O. Wooton 307 , August 10, 1897 (N); Union County, Cross L. Ranch, head of Cimarron Canyon, D. Griffiths 4305, May II, I903 $(\mathrm{B}, \mathrm{N})$.

Colorado.- Montezuma County, Mancos, Alice Eastwood 22, June I891 (N); La Plata County, Durango, Alice Eastwood 23, June I89r (N); Saguache County, Cochetopa National Forest, near Big Meadows, alt. $9500 \mathrm{ft}$., $W$. $O$. Sanders, July 8, I9r6 (B); Conejos County, Los Pinos, alt. 7000 ft., C. F. Baker 270 (in part), May I 899 (F, N); Las Animas County, Stonewall, Johnston and Hedgcock 498, June I8, I9I7 (B); Costilla County, Blanca, alt. $775^{2} \mathrm{ft}$,, E. R. Warren 72 ; July I6, I912 (B); Pikes Peak district, Little Fountain Creek, J. C. Blumer 5, 6, September 5, 1903 (B); Manitou, alt. $6000 \mathrm{ft}$, $M$. E. Jones 30 , May 8,1878 (N, twigs pubescent); Park County, Cassells, E. W. Cathcart, June $1904(\mathrm{~N})$; Lat. $39^{\circ}-4 \mathrm{I}^{\circ}$, Hall and Harbour $5^{24}, \mathrm{I} 862$ (FBb); Routt County, Walcott, Alice Eastwood I 7 (in part), July I89 г (FBb).

South Dakota.-Custer County (Black Hills), Beaver Creek, Mayo, W. H. Over I857, June I8, I9I4 (N).

Wyoming.-Albany County, Little Laramie River, L. N. Goodding 5, 6, June I4, I90I (B); foothills west of Islay, alt. $7300 \mathrm{ft.}$, Merritt Cary 313a, June 25, I $909(\mathrm{~N})$.

SALIX LUTEA platyphylla, n. var. $-S$. cordata var. Bebb in KING, U.S. Geol. Explor. 4oth Parallel 5:325. I871.-Shrub or small tree $3^{-6 \mathrm{~m}}$. tall; branchlets virgate or somewhat divaricate, yellow, shining, glabrous; buds yellow: stipules mostly small, semicordate to sublunate; petioles very slender, 8- I5 $\mathrm{mm}$. long, yellow, glabrous; blades differing from those of the species in being broader and shorter, elliptic-obovate, acute or short-acuminate at apex, broad and rounded or obliquely subcordate to cordate at base, $1 \cdot 5^{-3} \mathrm{~cm}$. wide, $4^{-8} \mathrm{~cm}$. long, common sizes being 2 by 4 , $2-2.5$ by $5,2-2.5$ by 6 , and 2.5 by $7 \mathrm{~cm}$., while sprout leaves reach such dimensions as $3 \cdot 5$ by $8,4 \cdot 5$ by 9 , and $4-4.5$ by I I cm.: aments same as in the species except that capsules are longer stalked, pedicels ranging from I to 2.5 or sometimes $3 \mathrm{~mm}$. in length.

This variety occurs rather commonly in the Wasatch Mountain system from southwestern Utah to Idaho and ranges thence northwestward into Oregon. It is probable that it is more abundant than the specimens cited would indicate. It is separated from $S$. lutea by the broad, ovate-lanceolate leaves and the more elongated pedicels, $1 \cdot 5^{-2} \cdot 5$ or $3 \mathrm{~mm}$. long. In flowering specimens, however, neither the broad leaves nor the elongated pedicels are certainly distinguishable. It is almost exactly the form described by BEBB as "S. cordata var." NutTall describes $S$. lutea as having ovate-lanceolate 
leaves, but states that they are more lanceolate than ovate. This statement agrees with NutTall's figure (Sylva $\mathbf{r}: 63 . p l .19$ ) and with the form of leaf on the cotype specimen, in which the pedicels are very short, scarcely exceeding I $\mathrm{mm}$. The following specimens are referred to this variety.

UтAн.-Beaver County, Milford, L. N. Goodding Io20, June 4, I902 (B, N); Juab County; Nephi, C. R. Ball 94, October 8, I907 (B, N) and (by F. D. Farrell from same plant) June I9, I909 (B); San Pete County, common in Coal Canyon, San Pitch Mountains, I. Tidestrom I304, June 24, I908 (N); Carbon County, Indianola, I. Tidestrom 2247, June I7, I909 (B); Salt Lake City, City Creek Canyon, alt. about $6000 \mathrm{ft} ., M$. E. Jones I702, May I I, I880 (N); alt. 5000 ft., S. G. Stokes, May I, I900 (N); P. A. Rydberg 6040, June 9, I905 (N); C.R. Ball I335, I336 (B, type) September I I, I908 (B, N); Farmington Canyon, near Salt Lake City, Pammel and Blackwood 36r8, July I4, I902 (B, I); Peterson, Weber River, alt. 6500 ft., Pammel and Blackwood 3903, July I8-24, I902 (B, I); Ogden Canyon, Ogden, A. E. Hitchcock I48I, August I9, I9I3 (N); Ogden, alt. $4300 \mathrm{ft} .$, M. E. Jones 6552, May 29, I889 (N).

Wyoming.-Sweetwater County, Bush Ranch, A. Nelson 7 I03, June 10, I900 (B).

IDAHo.-Bear Lake County, Montpelier, J. F. McBride I 7, May I5, I9ro (G, N with specimen of $S$. caudata); Canyon County, along the river, Emmett, alt. $2200 \mathrm{ft}$., J. F. McBride 790, April 29, I9II (N).

Oregon.-Blue Mountains, head of Otis Creek, W. C. Cusick r645, June I5, I $897(\mathrm{~N})$; Sherman County, Moro, C. $R$. Ball I853, August 4, I9I4 (B, N), C.R. Ball 2010, 20I I, June 29, I9I5 (B, C, F, G, I, N, R); Grass Valley, C. R. Ball 2012, June 30, I915 (B); Des(c)hutes River, Thos. Howell, May I886 (N).

Nevada.-Humboldt County, Santa Rosa National Forest, mouth of Hansen Creek Canyon, alt. $4800 \mathrm{ft}$., B. S. Martineau 26 (in part), May 7, I9I 5 (B, Fs).

Salix monochroma, n. sp.-S. cordata in part, of various authors treating of the Pacific northwest, not of Muhl.-S. pyrifolia as interpreted by BALL, in Coulter and Nelson, New Man. Rocky Mt. Bot. p. I33. I909, not of ANDERSSON, I867, or of SCHLEICHER, I8I5. - S. rotundifolia Nutt., N. A. Sylva I:75. I842, not Trautvetter, I832.-Low shrub, with slender, glabrous, shining branchlets and small stipules: leaves obovate-oval or ovate, shortacuminate, $4-8 \mathrm{~cm}$. long, crenulate-serrulate, thin, deep green and glabrous on both sides: aments appearing with the leaves, pistillate short-pedicelled lax; scales lanceolate-oblong, acute, dark, thinly pilose; capsule lanceolate, acute, $5^{-6.5} \mathrm{~mm}$. long, glabrous; pedicel 2-4 mm. long, style about $0.5 \mathrm{~mm}$. long; staminate ament sessile, slender; stamens 2, filaments glabrous, more or less united. 


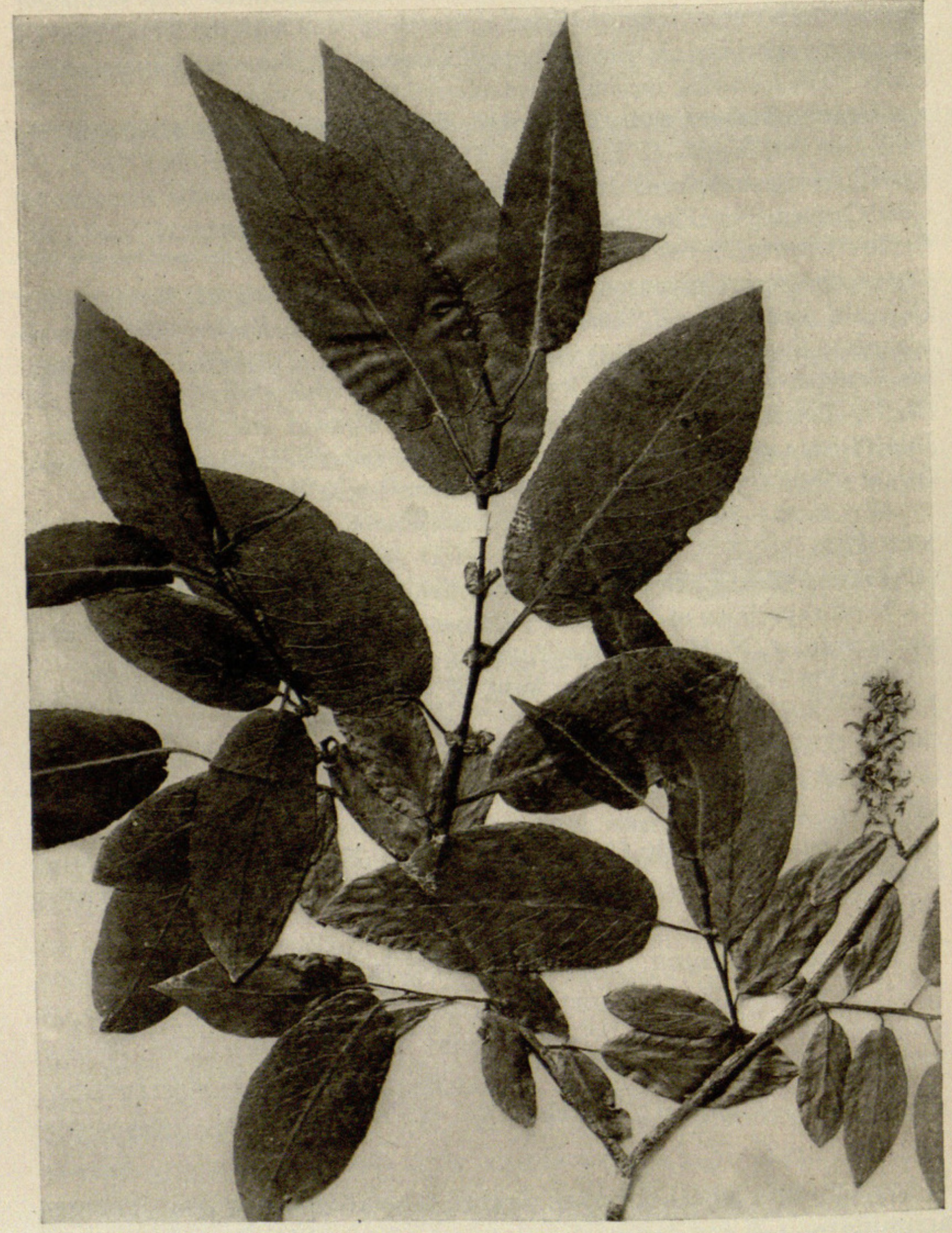

FIG. 1.-Salix monochroma Ball: portion of Coville and Kearney 24I, from Idaho; leaves typical but ament smaller than usual (about twó-thirds natural size). 
Low shrub, I-3 m. high; bark gray; branchlets slender, mostly elongated and virgate, sometimes shorter and divaricate, yellowish or bright chestnut to brown, glabrous, shining, full of leaf scars; buds slender, $4^{-7} \mathrm{~mm}$. long, acute, chestnut to dark brown, glabrous, inconspicuous: leaves stipulate, petiolate; stipules narrowly ovate to lunate, crenate-serrulate to denticulate, color and texture as in blades; petioles slender, $4^{-8}$ or $10 \mathrm{~mm}$. long, or to ${ }_{5} 5 \mathrm{~mm}$. long on sprout leaves, yellowish to dark brown, glabrous or puberulent; blades elliptic-oblanceolate to obovate-oval or ovate, acute to short-acuminate, or distal ones acuminate, $4-8 \mathrm{~cm}$. long, I. $5-4 \mathrm{~cm}$. wide, common sizes being 4 by 2,5 by $2.5,6$ by $2.5^{-} 3 \cdot 3,7$ by $2.5^{-}$ $3.5,8$ by 3 , rounded to truncate or slightly cordate at base, glandular crenate-serrulate, those on luxuriant sterile branchlets and sprouts much larger, 8 by 4 or 1o by $3.5 \mathrm{~cm}$., all thin, translucent, deep rich green on both sides, primary and secondary veins slender and somewhat raised on both surfaces, glabrous, at first thinly pilose-pubescent: aments slender, lax, appearing with the leaves, on short leafy peduncles; pistillate peduncle $5^{-8}$ or sometimes I $3 \mathrm{~mm}$. long, pubescent, bearing $2-4$ small leaves $\mathrm{I}-3 \mathrm{~cm}$. long; staminate aments nearly sessile; pistillate ament $2.5^{-6} \mathrm{~cm}$. long, I. $5^{-2} \mathrm{~cm}$. wide, lax; capsule lanceolate or rostrate from a subovoid base, 5-7 mm. long, glabrous; pedicel slender, $2-4 \mathrm{~mm}$. long; style $0.4-0.6 \mathrm{~mm}$. long, stigmas short, stout, mostly notched; scales elliptical-oblong or oblanceolate, light brown, drying black, acute or obtusish, thinly clothed outside and more densely so inside with long crinkly hairs; gland I, linear-clavate, elongated, sometimes I. $3 \mathrm{~mm}$. long, usually shorter; staminate aments sessile, $2 \cdot 5^{-6} \mathrm{~cm}$. long (subtended by $2-3$ leaves $\mathrm{I}-2 \mathrm{~cm}$. long), I cm. wide, slender, scales as in pistillate aments; stamens 2 , filaments glabrous, united for $0.5^{-0.7}$ of their length.

S. monochroma ranges from the Yellowstone Park of northwestern Wyoming and adjacent Montana to the Willamette Valley of western Oregon and north to southern British Columbia and southern Alberta. It is a shrub of stream banks in the mountains of this section. Apparently it ranges in altitude from about sea level (Portland) to 5000 or $6000 \mathrm{ft}$. ( 1500 to $1800 \mathrm{~m}$.) in the mountains, or occasionally to somewhat higher elevations. The flowers appear from about April I5 to May I5, and fruit follows in due season. At the higher altitudes the dates are considerably later. The writer was in error in placing 
this species under the name $S$. pyrifolia in the Nerw Manual of Rocky Mountain Botany. This was due to a misinterpretation of ANDERsson's species. This species is found quite commonly in at least four states and sparingly in others, and is represented by fairly abundant herbarium material. It seems never to have been described previously, however, unless NutTaLL's rotundifolia is correctly interpreted as belonging here. Nelson's 6ror from the Yellowstone Park comes the nearest of any of the specimens cited to matching NutTalL's description.

$S$. monochroma is most closely related to $S$. mackenziana on the one hand, and to $S$. pseudomyrsinites on the other. From $S$. mackenziana it is separated by the very thin leaves, more ovate in outline and never even glaucescent, but colored deep green alike on both sides. From $S$. pseudomyrsinites it may be separated by the much thinner and broader leaves, less glandular, and with much more slender veins. The pedicels also are shorter and usually glabrous. The following specimens are referred to this species.

Wyomrng.-Yellowstone National Park, E. A. Mearns 633, May I I, II I2, June $\mathrm{I}_{5}, \mathrm{I}_{3} 63$, June $24, \mathrm{I}_{902}(\mathrm{~N})$; in a ravine in the woods, Obsidian Creek, 2־4 ft. high, Aven Nelson 6ror, July 24, I899 (B).

Montana.-Livingston, E. W. Scheuber, June I, Igor (N).

IDAHo.-No locality (probably Boise or northward), Coville and Kearney 24I (N), 244, May I899 (B, N); Cuddy Mountains, Washington County, alt. $6000 \mathrm{ft}$., M. E. Jones 6547 , July I I, 1899 (N); Nez Perces County, valley of Hatwai Creek, Sandberg, MacDougal, and Heller 39, April 24 (G, N, 935072, type, female; 242995 , type, male), 70, April 28 (N); valley of Clearwater River (on island) 96, May 2 (F, G, N); valley of Peter Creek, I I 7, May 4 (FBb 2679, $\mathrm{G}, \mathrm{N}$ ); canyons, valley of Lake Waha, 21 5 , May $2 \mathrm{I}(\mathrm{FBb} 2828, \mathrm{G}, \mathrm{N})$; along Hatwai or Peter Creeks, Iо46, May 4, or 10, 1892 (N, 2 sheets); about Lewiston, A. A. and E. G. Heller 2942, April 23, 1896 (N); Latah County: L. F. Henderson 2880 (Wessels), 7894 (FBb); along Paradise Creek, near Moscow, Henderson 2882 (in part), June 2, I894 (FBb); along the Potlatch River, near Juliaetta, Henderson 2883, April 21, I894 (FBb).

Oregon.-Blue Mountains, mostly Union County: common along streams, Union County, Cusick 875, I880; alt. 8000 ft., Cusick 968 (in part), September I882 (N); Crane Prairie, South Blue Mountains, Cusick 1652 (in part), June 17 , I897 (N); stream banks, Cusick I845, April 26, May 9, September I898 (N); bank of Catherine Creek, alt. $3500 \mathrm{ft}$., Cusick 2383, May 30, June 28, I900 (F, G, N); Union, G. R. Hyslop 2058, July I8, I916 (B); Wallowa County: along Chesnimnus Creek, Chico Station, Imnaha National Forest, alt. about I000 m., Coville 2328, May 27, 1907 (N); Headwaters of Mud Creek, alt . about I $350 \mathrm{~m}$., Coville 2390, June 8, 1907 (N); Umatilla County, ford of Umatilla River, South of Mission and 5 miles east of Pendleton, C. R. Ball 2089, August 20, I9I7 (B); Grant County, Izee, Griffiths and Hunter 199, July I5, I902 (B); Deschutes River, Thomas Howell, May 9, I885 (FBb); Bend, on Deschutes River, E. Nelson, May 22, I905 (B); Linn County, Fish 
Lake, F. A. Walpole 305, August I, I899 (N); Portland, L. F. Henderson, I886 (FBb 6234).

Washington.-Whitman County, Pullman, A. D. E. Elmer iri, May I 897 (B); C. V. Piper 3598, May r3, r898 (B); Walla Walla County, Waitsburg, R. M. Horner 446, April $22(\mathrm{~N}), 447$, April 9, 1897 (N); (west) Klickitat County, Columbia River, W. N. Suksdorf 40, April 25, r884 (B); no locality, probably Klickitat County, E. P. Sheldon 8124, I897 (N); Kittitas County, Wenatchee Mountains, Coville II77, September 4, r9or (N); Okanogan County, along Ashnola River, Sheep Mountain-Bald Mountain Trail, Okanogan Forest, alt. I630 m., W. W. Eggleston I3395, August 2, rgr6 (N).

AlberTA.-Rocky Mountain Park, vicinity of Banff, N. B. Sanson Ii9, June 9 and 20, I9I I ; 257, 260, 262, 263,264, 266, 267, 299, 302, 3II, between July 4 and July I $_{5}$, I9Ir; 34r, 380, 387,2038 , between August 2 and August I4, I9II; 5II, June 29, I9I2, 三July I, I9I2 (B, RMP).

SALIX FARRAE Walpoleii Coville and Ball, n. var.-Low shrub, $0.5^{-2} .5 \mathrm{~m}$. high; bark probably dark gray; branchlets substoutish, the older dark gray to brown, those of the season, or of two years' growth, mostly short, divaricate, dark brown to black, the youngest pubescent with gray hairs, becoming glabrate or glabrous, all rather closely beset with bud scars; buds (seen only on flowering and fruiting specimens) minute or small, $\mathrm{I}-3 \mathrm{~mm}$. long, lanceolateconic, black, thinly pubescent or glabrous: leaves mid-sized, petiolate, minutely stipulate; stipules minute to small, lanceolate or semicordate to ovate, acute, entire or denticulate, $\mathrm{I}-5 \mathrm{~mm}$. long; petioles slender, 2-Io mm. long, yellowish to dark brown, pubescent, becoming glabrous; blades elliptic-lanceolate to obovate, acute or abruptly short-acuminate, $4-8 \mathrm{~cm}$. long, $2-3 \cdot 3 \mathrm{~cm}$. wide, common sizes being 5 by $2-2 \cdot 5,6$ by $2-2 \cdot 5,7$ by $2.4-3$, and 8 by $3 \cdot 3 \mathrm{~cm}$., narrowed to somewhat rounded at base, entire or shallowly and rather remotely crenulate, thin, glabrous, green above, glaucous beneath, coarsely reticulate with slender veins on both surfaces: aments slender, rather lax, appearing with the leaves, on leafy peduncles; pistillate peduncle $\mathrm{I}-2 \mathrm{~cm}$. long, bearing $2-4$ leaves $2-4 \mathrm{~cm}$. long; the staminate $5^{-10} \mathrm{~mm}$. long, bearing $2-3$ leaves I. $5^{-2} \cdot 5 \mathrm{~cm}$. long: pistillate aments $2-5$ or $6 \mathrm{~cm}$. long, I $2-15 \mathrm{~mm}$. wide, lax in fruit, rachis scantily tomentose; capsule narrowly lanceolate-rostrate, or conic-rostrate, $5^{-7} \mathrm{~mm}$. long, mostly obtuse, brown, glabrous; pedicel slender to stoutish, $\mathrm{I}-\mathrm{I} .5 \mathrm{~mm}$. long, glabrous; style very short, $0.2-0.3 \mathrm{~mm}$. long, stigmas short, 
notched; gland about $0.5 \mathrm{~mm}$. long; scales oblanceolate, obtusish or acute, pale brown, nearly glabrous outside, thinly pilose inside, about $0.8 \mathrm{~mm}$. long: staminate aments slender, spreading, $2-3 \mathrm{~cm}$. long, $\mathrm{I} \mathrm{cm}$. wide; stamens 2, filaments glabrous, free; anthers short, obovate to nearly round, reddish or purplish; scales as in pistillate ament.

Salix Farrae Walpoleii is separated readily from the species by the pubescent-pilose young twigs, the broader, more obovate leaves, the longer and laxer aments, and the shorter styles. Walpole's no. I624 in the United States National Herbarium is designated as the pistillate type. His no. 1742 has the best aments of any of the three staminate specimens seen and is designated as the staminate type. The variety flowers from about June 20 onward through July or early August, according to location. This willow rather closely resembles S. balsamifera (Hooker) Barratt, from which, however, it is readily separated by the entire leaves, seldom rounded and never cordate at base, the short pedicels, and somewhat shorter styles. Its nearest relative on the $S$. cordata side is $S$. mackenziana (Hook.) Barr., from which it is separated easily by the thin, entire, elliptic-obovate leaves, and more especially by the short pedicels. The variety is named for F. A. WALPOLE, since deceased, who collected several specimens of it in the vicinity of Port Clarence, near Cape Prince of Wales, Bering Strait, the most western locality at which it has been found. The specimens referred to it are cited later. So far as known, it is the only member of the section CoRDATAE with an exclusively Arctic distribution.

ALASKa.-Vicinity of Port Clarence; north side and east end of Grantley Harbor, F. A. Walpole I594, 3-4 ft. high, July 29, I 901 (N); rocky banks, northwest shore of Imunik Basin, F. A. Walpole $1624,5-8 \mathrm{ft}$. high, July 30, Igor (N, type); banks of Fuksuk Channel, F. A. Walpole $174^{2}, 3^{-4} \mathrm{ft}$. high, August 5, rgor (B, N); Cape Nome, F. O. Blaisdell, summer 1900; Fort Hamlin, Yukon River, to Bergman, Koyukuk River, Dall River, 75 miles above the mouth, W. C. Mendenhall, June 25, Igor (N, two sheets); Valley of Alaskuk River, small willow, $2-4 \mathrm{ft}$. high, found along river, 30 miles above its mouth, W. C. Mendenhall, July 21, IgoI (N); along Help-me-Jack Creek, near camp, W. C. Mendenhall, common in river bottoms, about $5 \mathrm{ft}$. high, July 26, I90I (N); Valley of Kobuck River, small bushy willow about $4 \mathrm{ft}$. high, on bank of small stream, W. C. Mendenhall, July 20, rgor (N); Seward Peninsula, A. J. Collier, $1900(\mathrm{~N})$.

SALIX Lasiolepis Bakeri (v. Seem.), n. comb.-S. Bakeri von Seemen, Bull. Torr. Bot. Club 30:635. 1903.-A shrub or small tree essentially like $S$. lasiolepis in most respects, except that the capsule is thinly pubescent, especially toward the apex. The 
capsule, $5^{-6} \mathrm{~mm}$. long, also appears to be slightly larger than in the species and the style slightly longer.

When von SeEmen described $S$. Bakeri he did not compare it with $S$. lasiolepis or mention that species in any way. He published two other species in the same paper, $S$. franciscana and $S$. ormsbyensis. In neither case did he indicate their relationships or mention other species in connection with them. We might infer either that American species were not well represented in the Berlin herbarium or that von SEEmen did not look them over. His description of $S$. Bakeri fits S.lasiolepis perfectly except in the one phrase "apex with short gray hairs" in reference to the capsule. All the evidence goes to show that the describer was unaware of $S$. lasiolepis rather than that he knowingly was segregating from it a new species with pubescent capsules. This variety is comparable to var. puberula under $S$. commutata.

Two specimens collected by $F$. A. Walpole, at Modoc Point, Klamath County $(2 \mathrm{Ig} 8,2200)$, on June $5,1902(\mathrm{~N})$, are similar to the specimens cited later. The capsule in the Klamath specimens, however, is longer $(6-8 \mathrm{~mm}$.), much resembling that of $S$. scouleriana. I have considered these two, therefore, to be hybrids between $S$. lasiolepis and $S$. scouleriana. It is possible that the plants here referred to var. Bakeri are hybrids also, but this is less probable. One striking character in the Klamath specimens is the elongated pedicel, I. $5^{-2} .5 \mathrm{~mm}$. in no. 2198 , which is longer than in either supposed parent.

CAlifornia.-Foothills near Stanford University, Santa Clara County, C. F. Baker 274, March 9 and May 10, 1902 (N, cotype); Berkeley, W. L. Jepson, March 24, August I5, I891 (N).

Bureau of Plant Industry

WASHINGTON, D.C. 


\section{$2 \mathrm{BHL}$ Biodiversity Heritage Library}

Ball, Carleton R. 1921. "Undescribed Willows of the Section Cordatae." Botanical gazette 71(6), 426-437. https://doi.org/10.1086/332864.

View This Item Online: https://www.biodiversitylibrary.org/item/109572

DOI: https://doi.org/10.1086/332864

Permalink: https://www.biodiversitylibrary.org/partpdf/224229

\section{Holding Institution}

Missouri Botanical Garden, Peter H. Raven Library

\section{Sponsored by}

Missouri Botanical Garden

\section{Copyright \& Reuse}

Copyright Status: Public domain. The BHL considers that this work is no longer under copyright protection.

This document was created from content at the Biodiversity Heritage Library, the world's largest open access digital library for biodiversity literature and archives. Visit BHL at https://www.biodiversitylibrary.org. 